\title{
Determination of virtual water content of rice and spatial characteristics analysis in China
}

\author{
L. J. Zhang, X. A. Yin, Y. Zhi, and Z. F. Yang
}

State Key Laboratory of Water Environmental Simulation, School of Environment, Beijing Normal University, Beijing, China

Correspondence to: X. A. Yin (yinxinan@bnu.edu.cn)

Received: 23 December 2013 - Published in Hydrol. Earth Syst. Sci. Discuss.: 22 January 2014

Revised: - Accepted: 2 May 2014 - Published: 6 June 2014

\begin{abstract}
China is a water-stressed country, and agriculture consumes the bulk of its water resources. Assessing the virtual water content (VWC) of crops is one important way to develop efficient water management measures to alleviate water resource conflicts among different sectors. In this research, the VWC of rice, a major crop in China, is taken as the research object. China covers a vast land area, and the VWC of rice varies widely between different regions. The VWC of rice in China is assessed and the spatial characteristics are also analysed. The total VWC is the total volume of freshwater both consumed and affected by pollution during the crop production process, including both direct and indirect water use. Prior calculation frameworks of the VWC of crops did not contain all of the virtual water content of crops. In addition to the calculation of green, blue and grey water - the direct water in VWC - the indirect water use of rice was also calculated, using an input-output model. The percentages of direct green, blue, grey and indirect water in the total VWC of rice in China were found to be 43.8, 28.2, 27.6 , and $0.4 \%$. The total VWC of rice generally showed a roughly three-tiered distribution, and decreased from southeast to northwest. The higher values of direct green water usage were mainly concentrated in Southeast and Southwest China, while the values were relatively low in Northwest China and Inner Mongolia. The higher direct blue water values were mainly concentrated in the eastern and southern coastal regions and Northwest China, and low values were mainly concentrated in Southwest China. Grey water values were relatively high in Shanxi and Guangxi provinces and low in Northeast and Northwest China. The regions with high values for indirect water were randomly distributed but the regions with low values were mainly concentrated in Northwest and Southwest China. For the regions with rela-
\end{abstract}

tively high total VWC the high values of blue water made the largest contribution, although for the country as a whole the direct green water is the most important contributor.

\section{Introduction}

The term virtual water was first proposed by Allan (1994) and defined as the water embodied in traded products. Later the concept of virtual water was modified by Hoekstra and Chapagain (2007) to indicate the water input required to generate a product or service. The virtual water content of a product is the freshwater embodied in the product, not in the real sense, but in the virtual sense. It refers to the volume of the freshwater both consumed and affected by pollution in producing the product, measured over its full production chain (Hoekstra et al., 2011). In water-stressed regions, limited water resources should be used efficiently by not allocating the majority of resources to the production of waterintensive products, but being made available for other economic purposes that can contribute more to the regional value added by consuming less water (Allan, 2002; Chapagain and Hoekstra, 2008). Assessing the virtual water content (VWC) of products is the basis for developing such water resource management practices.

Hoekstra and Hung (2002) estimated the VWC of crops for many countries of the world. In their research, the crop VWC was determined by estimating the accumulated crop evapotranspiration over the growing period, and the VWC was not divided into subtypes. To better understand the VWC of crops, many scientists now divide the VWC into subtypes and calculate them separately. The calculation of green (effective precipitation) and blue water (irrigation 
water withdrawn from ground or surface water) was initially proposed. Research has been performed at global, national, provincial, and river basin scales. For example, Rost et al. (2008) made a global estimate of agricultural green and blue water consumption. Siebert and Döll (2010) computed the green and blue VWC of crops at a global scale, and found that the global average VWC of cereal crops was $1109 \mathrm{~m}^{3} \mathrm{t}^{-1}$ of green water and $291 \mathrm{~m}^{3} \mathrm{t}^{-1}$ of blue water. Scientists have also added grey water to the VWC, defined as freshwater that is required to assimilate the pollutant load based on natural background concentrations and existing ambient water quality standards. Chapagain et al. (2006) first calculated the grey water in the VWC of crops, finding that the global VWC of rice was an average of $1325 \mathrm{~m}^{3} \mathrm{t}^{-1}$ and, further, that grey water occupied about $8 \%$ of the total VWC (Chapagain and Hoekstra, 2011). Mekonnen and Hoekstra (2011a) quantified grey VWC of global crop productions for the period 19962005 , and found that green, blue and grey water accounted for 78,12 and $10 \%$ in the total VWC of crops.

China is one of the world's 13 most water-poor countries (Yu et al., 2006). In 2012, per capita use of water resources in China was only $2100 \mathrm{~m}^{3}$, less than $30 \%$ of the world per capita consumption. Agriculture is the largest water user in China, accounting for nearly $70 \%$ of total water withdrawals (Ministry of Water Resources, 2012). Studies on the VWC of crops in China are relatively limited. Liu et al. (2007), from the perspective of crop water productivity, estimated the virtual water use of winter wheat. Sun et al. (2013a) used the crop water requirement to calculate the China average VWC of wheat, maize and rice, and found the proportions of green and blue water to be 50.98 and $49.02 \%, 76.27$ and $23.73 \%$, and 61.90 and $38.10 \%$, respectively. The VWC of rice was relatively low in the eastern part of Northeast China, middlelower reaches of the Yangtze River and the eastern part of Southwest China. In contrast, the high values of VWC for rice were located in the west of Inner Mongolia and south of the Xinjiang Uygur autonomous region. Sun et al. (2013b) estimated the VWC of crops as $3.91 \mathrm{~m}^{3} \mathrm{~kg}^{-1}$ in the Hetao irrigation district of China. The percentage of blue water was relatively high $(90.91 \%)$, while the share of green water was small $(9.09 \%)$. However, these studies all ignored grey water.

Rice as a cereal grain is the most widely consumed staple food for a large part of the population, especially in Asia. According to data from FAOSTAT, rice is the grain with the second-highest worldwide production, after maize. China is the biggest rice-producing country in the world. In 2007, the planting area of rice was the second largest in China (about 29 million hectares), comprising $34 \%$ of the total planting area of grain crops. Rice production is the largest grain production in China (around 186 million tonnes), accounting for $41 \%$ of the total grain (Ministry of Agriculture of the People's Republic of China, 2008). There is no research on the total VWC of rice and spatial distribution characteristics in China at the provincial scale by actual total water use. China covers a vast land area, and the VWC of rice varies widely between different regions. The VWC of rice in China is assessed and the spatial characteristics are also analysed.

Prior research on crop VWC determination provides a good framework for this work. However, prior calculation frameworks of VWC of crops have some defects. Some use the water requirement of crops instead of actual water use, and others ignore the freshwater affected by pollution during crop production. Besides, in all previous calculation frameworks the indirect water use of crops was also ignored. On the basis of the previous frameworks, in addition to direct water use (blue, green, and grey water), we also consider indirect water (the sum of the virtual water of all products consumed in the process of rice planting). In this paper, we calculate the total VWC of rice for 29 Chinese provinces, autonomous regions, and municipalities in 2007, including both direct and indirect water use. Because of the lack of data, Tibet is not taken into account; and no rice is planted in Qinghai, so Qinghai is not taken into account either. The spatial distribution characteristics of the VWC of rice are also analysed.

\section{Methodology and data}

\subsection{Methodology}

To reflect water consumption during crop production, direct and indirect water were taken into account. Due to lack of data, we cannot divide the $\mathrm{VWC}_{\text {indirect }}$ into $\mathrm{VWC}_{\text {indirect, green }}$, $\mathrm{VWC}_{\text {indirect, blue }}$ and $\mathrm{VWC}_{\text {indirect, grey }}$ :

$$
\begin{aligned}
\mathrm{VWC}_{\text {total }} & =\mathrm{VWC}_{\text {indirect }}+\mathrm{VWC}_{\text {direct }} \\
& =\mathrm{VWC}_{\text {indirect }}+\mathrm{VWC}_{\text {direct, green }} \\
& +\mathrm{VWC}_{\text {direct, blue }}+\mathrm{VWC}_{\text {direct, grey }}
\end{aligned}
$$

where $\mathrm{VWC}_{\text {total }}$ is the total volume of freshwater both consumed and affected by pollution during the crop production process $\left(\mathrm{m}^{3} \mathrm{~kg}^{-1}\right) ; \mathrm{VWC}_{\text {indirect }}$ is the freshwater both consumed and affected by pollution that can be associated with the production of the goods and services or the inputs used during the crop production process $\left(\mathrm{m}^{3} \mathrm{~kg}^{-1}\right)$; $\mathrm{VWC}_{\text {direct }}$ is the freshwater both consumed and affected by pollution that is associated with direct water use during the crop production process $\left(\mathrm{m}^{3} \mathrm{~kg}^{-1}\right)$; $\mathrm{VWC}_{\text {direct, green }}$ is the precipitation consumed in the crop production process $\left(\mathrm{m}^{3} \mathrm{~kg}^{-1}\right)$; $\mathrm{VWC}_{\text {direct, blue }}$ is the surface water or groundwater consumed in the crop production process $\left(\mathrm{m}^{3} \mathrm{~kg}^{-1}\right)$; and $\mathrm{VWC}_{\text {direct, grey }}$ is the freshwater required to assimilate the load of pollutants during the crop production process $\left(\mathrm{m}^{3} \mathrm{~kg}^{-1}\right)$.

\subsubsection{Indirect water of crops}

The input-output model represents the monetary trade of products and services among different sectors of an 
economic system (Leontief, 1941), and is adopted to calculate the indirect virtual water of crops supplied by each economic sector. The calculations are as follows (Chen, 2000; Kanada, 2001; Zhao et al., 2009; Zhang et al., 2011).

1. Direct consumption coefficient matrix. The inputoutput table is used because it reflects the contact of the materials and technologies. This contact is reflected through the direct consumption coefficient:

$\mathbf{A}=\left|a_{i j}\right|=\left|x_{i j} / x_{i}\right|$,

where $\mathbf{A}$ is the direct consumption coefficient matrix ( $n \times n$ dimensional matrix) in the IO table; $a_{i j}$ is the direct consumption coefficient, which means the monetary volume of products of sector $i$ directly consumed by sector $j$ when producing one unit product; $x_{i j}$ is the monetary volume of products from sector $j$ consumed by sector $i$ in its production process (RMB); and $x_{i}$ is the output of sector $i$ (RMB).

2. Complete consumption coefficient matrix. Compared with the direct consumption coefficient, the complete consumption coefficient can more accurately measure the direct and indirect costs (the sum of the direct and indirect costs is completely consumed) of products or services from other sectors:

$\mathbf{B}=\left|b_{i j}\right|=(\mathbf{I}-A)^{-1}-\mathbf{I}$,

where $\mathbf{B}$ is the complete consumption coefficient matrix $\left(n \times n\right.$ dimensional matrix) in the IO table; $b_{i j}$ is the complete consumption coefficient, which means the monetary volume of products of sector $i$ directly and indirectly consumed by sector $j$ when producing one unit product; and $\mathbf{I}$ is a unit diagonal matrix.

3. Water use coefficient. To account for indirect water, it is necessary to compute the water use coefficient of different sectors, which is the water needed to produce one monetary unit (RMB):

$\mathrm{DWC}_{i}=w_{i} / x_{i}$,

where $\mathrm{DWC}_{i}$ is the direct water coefficient of sector $i$ $\left(\mathrm{m}^{3} \mathrm{RMB}^{-1}\right)$ and $w_{i}$ is the direct water consumption of sector $i\left(\mathrm{~m}^{3}\right)$. DWC $i$ is the amount of direct water intake to produce one monetary unit of production.

4. Indirect water of agriculture. Indirect water consumption of agriculture is the amount of total water input from other sectors.

$\mathrm{VW}_{\text {indirect }}^{\mathrm{a}}=\sum_{i=1}^{n}\left(\mathrm{DWC}_{i} \times b_{i \mathrm{a}}\right) \times C_{\mathrm{a}}$,

where $\mathrm{VW}_{\text {indirect }}^{\mathrm{a}}$ is the indirect water consumption of agriculture $\left(\mathrm{m}^{3}\right) ; b_{i a}$ is the complete consumption coefficient of sector $i$ for agriculture; and $C_{\mathrm{a}}$ is the total consumption of agriculture (RMB).
5. Indirect water consumption of a crop. $\mathrm{VWC}_{\text {indirect }}^{\mathrm{i}}$ $\left(\mathrm{m}^{3} \mathrm{~kg}^{-1}\right)$ is calculated according to the proportion of indirect water use of crop $i$ in the total indirect water consumption of agriculture:

$\mathrm{VWC}_{\text {indirect }}^{i}=\frac{\mathrm{VW}_{\text {indirect }}^{\mathrm{a}} \alpha_{i}}{\mathrm{SA}_{i} \times Y}$,

where $\mathrm{VWC}_{\text {indirect }}^{i}$ is the indirect water consumption of crop $i\left(\mathrm{~m}^{3} \mathrm{~kg}^{-1}\right) ; \alpha_{i}$ is the proportion of indirect water use of crop $i$ in the total indirect water consumption. Because of lack of data, we assume that the planting cost is proportional to the indirect water use. $\mathrm{SA}_{i}$ is the sown area of crop $i$ (ha); and $Y$ is the crop yield per unit area $\left(\mathrm{kg} \mathrm{ha}^{-1}\right)$. Thus $\alpha_{i}$ can be calculated as follows:

$\alpha_{i}=\frac{\mathrm{PC}_{i} \times \mathrm{SA}_{i}}{\sum_{i=1}^{n}\left(\mathrm{PC}_{i} \times \mathrm{SA}_{i}\right)}$,

where $\mathrm{PC}_{i}$ is the planting cost of crop $i$ per unit area $\left(\mathrm{RMB} \mathrm{ha}^{-1}\right)$.

\subsubsection{Direct green water of crops}

Direct green water use is the lesser of potential crop evapotranspiration and effective precipitation. Effective precipitation is defined as the amount of precipitation that enters the soil and will be available in the soil for crop growth (Sun et al., 2013b):

$\mathrm{VWC}_{\text {direct, green }}=\frac{10 \min \left(\mathrm{ET}_{\mathrm{c}}, P_{\mathrm{e}}\right)}{Y}$,

where $\mathrm{ET}_{\mathrm{c}}$ is the crop evapotranspiration during the growing period $(\mathrm{mm})$ and $P_{\mathrm{e}}$ is the effective precipitation over the crop growing period $(\mathrm{mm})$, calculated by the CROPWAT model using monthly climatic data (mm) (Clarke, 1998; FAO, 2003).

Crop evaporation during the growing period is calculated as follows (Allen et al., 1998):

$\mathrm{ET}_{\mathrm{c}}=\mathrm{ET}_{\mathrm{o}} \times k_{\mathrm{c}}$

where $k_{\mathrm{c}}$ is the crop coefficient, reflecting the differences in physical and physiological factors between the actual and reference crops and $\mathrm{ET}_{\mathrm{o}}$ is the soil evaporation of the reference underlying surface $\left(\mathrm{mm} \mathrm{d}^{-1}\right)$, calculated by the FAO Penman-Monteith formula (Allen et al., 1998).

\subsubsection{Direct blue water of crops}

The direct blue water of a crop is calculated using the irrigation water consumption, $I_{\mathrm{c}}$. The irrigation water consumption is the net artificial application of water use by crops, which does not include the irrigation water losses during the transport process from the water sources to cropland and the 
return flows of irrigation water. The direct blue water is calculated according to the proportion of irrigation water consumption of crop $i$ in the total irrigation water consumption of the irrigation district (Sun, 2013b):

$\mathrm{VWC}_{\text {direct, blue }}^{i}=I_{\mathrm{c}}^{i} / Y=\frac{W_{\mathrm{A}} \beta_{i}}{\mathrm{SA}_{i} \times Y}$,

where $I_{\mathrm{c}}^{i}$ is the irrigation water consumption of crop $i$ per unit area $\left(\mathrm{m}^{3} \mathrm{ha}^{-1}\right), W_{A}$ is the irrigation water consumption of the irrigation district $\left(\mathrm{m}^{3}\right)$ and $\beta_{i}$ is the proportion of irrigation water use of crop $i$ in the total irrigation water consumption of the irrigation district. $\beta_{i}$ can be calculated as follows:

$$
\beta_{i}=\frac{\left(\mathrm{ET}_{\mathrm{c}}^{i}-P_{\mathrm{e}}^{i}\right) \times \mathrm{SA}_{i}}{\sum_{i=1}^{n}\left[\left(\mathrm{ET}_{\mathrm{c}}^{i}-P_{\mathrm{e}}^{i}\right) \times \mathrm{SA}_{i}\right]},
$$

where $\mathrm{ET}_{\mathrm{c}}^{i}$ is the crop evapotranspiration of crop $i$ during the growing period $(\mathrm{mm}), P_{\mathrm{e}}^{i}$ is the effective precipitation over the crop $i$ growing period $(\mathrm{mm})$ and $\mathrm{SA}_{i}$ is the sown area of crop $i$ (ha).

\subsubsection{Direct grey water of crops}

In this study we quantify direct grey water related to nitrogen use only. The direct grey water is calculated by multiplying the fraction of nitrogen that leaches or runs off by the nitrogen application rate and dividing this by the difference between the maximum acceptable concentrations of nitrogen and the natural concentration of nitrogen in the receiving water body and by the actual crop yield (Mekonnen and Hoekstra, 2011a). Because of lack of data, the natural nitrogen concentrations were assumed to be 0 . On average, $10 \%$ of the applied nitrogen fertilizer is lost through leaching (Chapagain et al., 2006). The maximum value of nitrate in surface and ground water recommended by the United States Environmental Protection Agency is $10 \mathrm{mg} \mathrm{L}^{-1}$ (Chapagain et al., 2006):

$\mathrm{VWC}_{\text {direct, grey }}=\frac{N_{\mathrm{c}} \times 10 \%}{10-N_{\mathrm{n}}} / Y$,

where $N_{\mathrm{c}}$ is the amount of nitrogen fertilizer consumption per hectare $\left(\mathrm{g} \mathrm{ha}^{-1}\right)$ and $N_{\mathrm{n}}$ is the natural concentration of nitrogen in the receiving water body $\left(\mathrm{mg} \mathrm{L}^{-1}\right)$.

\subsection{Data}

The 2007 climate data for 29 regions, including monthly average maximum temperature, monthly average minimum temperature, relative humidity, wind speed, precipitation, and sunshine hours, are taken from the National Climatic Centre (NCC) of the China Meteorological Administration (CMA). The agricultural data, including crop yield and sown area, are taken from the China Agricultural Yearbook (Ministry of Agriculture of the People's Republic of China, 2008).

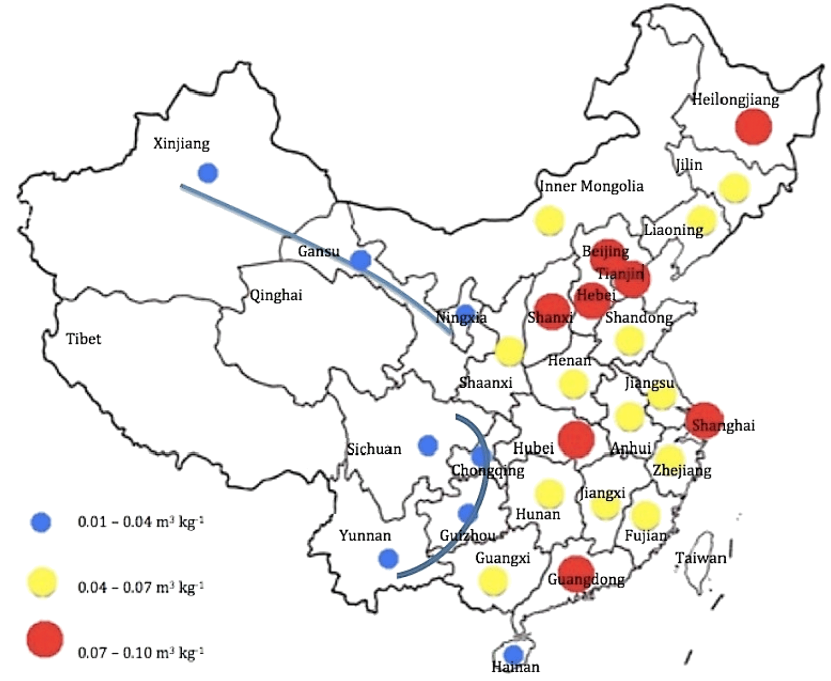

Figure 1. Indirect water of rice $\left(\mathrm{m}^{3} \mathrm{~kg}^{-1}\right)$.

The average amount of nitrogen fertilizer of rice per unit area is taken from Li et al. (2010) and Zhang et al. (2008, 2009). The irrigation water consumption for the 29 regions is taken from the Water Resources Bulletins (2007) of the 29 regions. Water data for various sectors in the regions are from the Statistical Yearbooks (2008) of the 29 regions. The IO data for the 29 regions come from the official IO tables (2007) of the 29 regions.

\section{Results}

\subsection{Indirect water of rice}

The $\mathrm{VWC}_{\text {indirect }}$ of rice varied between 0.001 and $0.010 \mathrm{~m}^{3} \mathrm{~kg}^{-1}$. The average $\mathrm{VWC}_{\text {indirect }}$ was $0.004 \mathrm{~m}^{3} \mathrm{~kg}^{-1}$. The regions with the same line had the same distribution characteristic of $\mathrm{VWC}_{\text {indirect }}$ of rice in Fig. 1. The input to agriculture in relatively underdeveloped regions was relatively small; relatively developed regions invest more money in agriculture. Northwest and Southwest China are relatively underdeveloped with relatively low $\mathrm{VWC}_{\text {indirect }}$ of rice. Beijing, Guangdong, and Shanghai are the three most developed regions and had the highest $\mathrm{VWC}_{\text {indirect }}$ of rice in 2007 (Fig. 1). We found that $\mathrm{VWC}_{\text {indirect }}$ of rice is directly related to the degree of regional economic development.

Of all sectors, the sector of forestry, animal husbandry, and fishery contributed the most $\mathrm{VWC}_{\text {indirect }}$ of rice, accounting for $52.2 \%$. The electricity and heat sector contributed $21.6 \%$ and the chemical industry sector contributed $9.6 \%$. The rest of the sectors contributed less. 


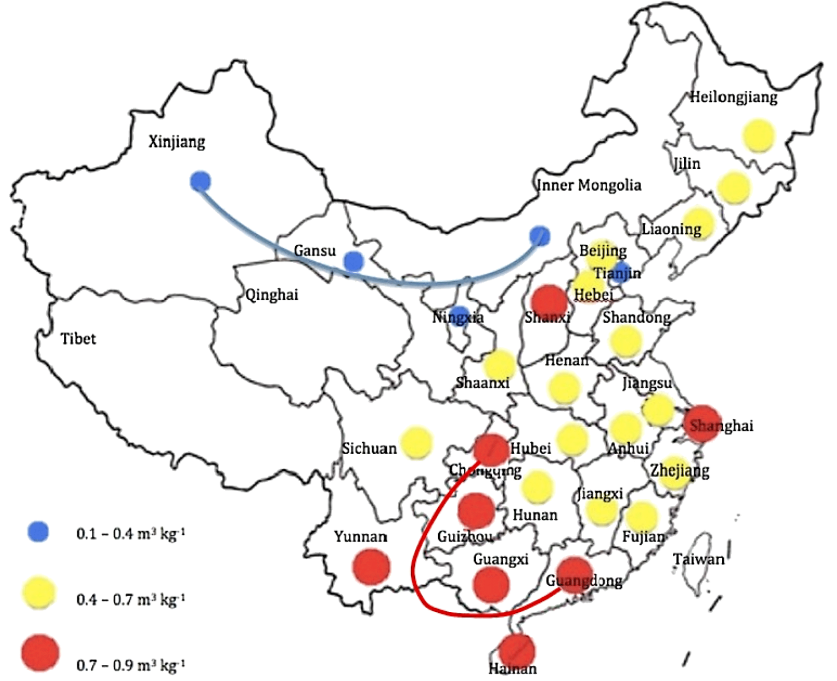

Figure 2. Direct green water of rice $\left(\mathrm{m}^{3} \mathrm{~kg}^{-1}\right)$.

\subsection{Direct green water of rice}

The regional differences in $\mathrm{VWC}_{\text {direct, green }}$ for rice were significant, owing to differences in climatic conditions and crop yields. The $\mathrm{VWC}_{\text {direct, green }}$ of rice for the 29 regions in 2007 ranged from 0.10 to $0.90 \mathrm{~m}^{3} \mathrm{~kg}^{-1}$. The average $\mathrm{VWC}_{\text {direct, green }}$ of rice was $0.59 \mathrm{~m}^{3} \mathrm{~kg}^{-1}$. $\mathrm{VWC}_{\text {direct, green }}$ of rice increased gradually from northern to southern regions (Fig. 2). The regional variability of $\mathrm{VWC}_{\text {direct, green }}$ of rice was in accordance with the distribution of precipitation in China. The regions with abundant precipitation usually have high $\mathrm{VWC}_{\text {direct, green }}$ of rice. Precipitation in southern regions of China is far greater than that in northern regions. Consequently, the $\mathrm{VWC}_{\text {direct, green }}$ of rice in southern regions would be higher than that in northern regions.

The regions with higher $\mathrm{VWC}_{\text {direct, }}$ green values were concentrated in Southeast China and Southwest China (Fig. 2). The high $\mathrm{VWC}_{\text {direct, green }}$ in these regions is a result of the high ratio between effective precipitation and rice yield. The regions in Southeast China and Southwest China had relatively low rice yields, much lower than the national average, and relatively high effective precipitation, more than $400 \mathrm{~mm}$. For example, the $\mathrm{VWC}_{\text {direct, green }}$ of rice was more than $0.80 \mathrm{~m}^{3} \mathrm{~kg}^{-1}$ in Hainan (Southeast China), Guangxi (Southwest China) and Yunnan (Southwest China). The

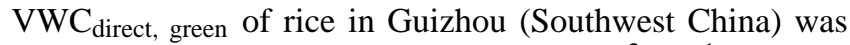
also relatively high, at more than $0.80 \mathrm{~m}^{3} \mathrm{~kg}^{-1}$. This is mainly because the effective precipitation over the growing period of rice in this region was more than $590 \mathrm{~mm}$, although rice yield in this region was higher than the national average.

The $\mathrm{VWC}_{\text {direct, }}$ green of rice in Northwest China and Inner Mongolia were relatively low (Fig. 2), because of high yields and low effective precipitation. Xinjiang (Northwest China) had the lowest $\mathrm{VWC}_{\text {direct, green }}\left(0.10 \mathrm{~m}^{3} \mathrm{~kg}^{-1}\right)$ because the

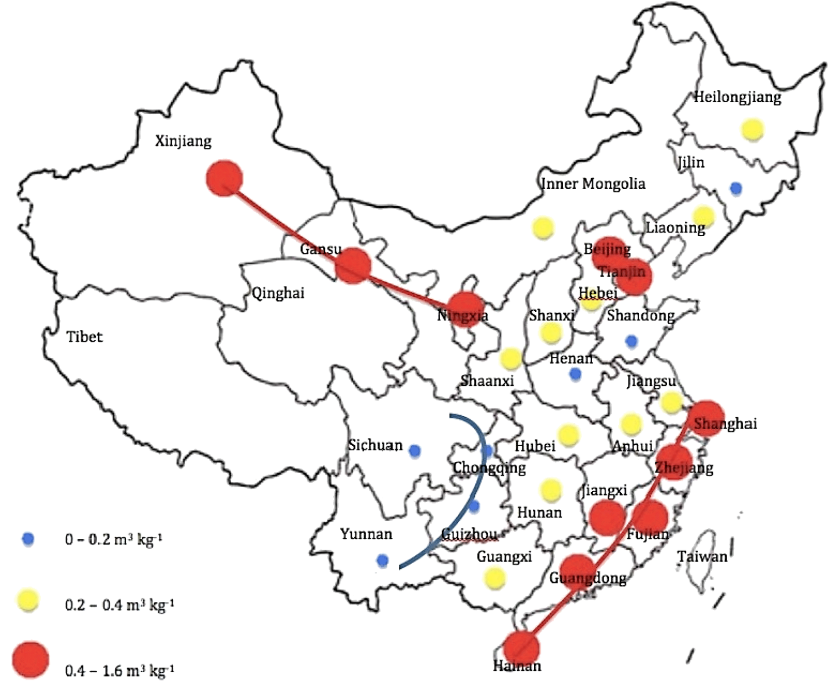

Figure 3. Direct blue water of rice $\left(\mathrm{m}^{3} \mathrm{~kg}^{-1}\right)$.

rice yield in Xinjiang was 1.32 times higher than the national average and the effective precipitation over the growing period was small, less than $90 \mathrm{~mm}$.

\subsection{Direct blue water of rice}

The differences in blue water requirements, actual irrigation water consumption and rice yields resulted in signifi-

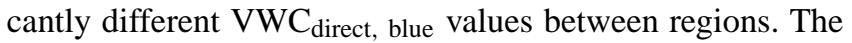
$\mathrm{VWC}_{\text {direct, blue }}$ values ranged from 0.07 to $1.65 \mathrm{~m}^{3} \mathrm{~kg}^{-1}$, and the average was $0.42 \mathrm{~m}^{3} \mathrm{~kg}^{-1}$. The regions with higher $\mathrm{VWC}_{\text {direct, blue }}$ of rice were mainly concentrated in the eastern and southern coastal regions and in Northwest China

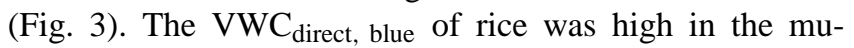
nicipalities of Beijing, Tianjin and Shanghai, at more than $0.83 \mathrm{~m}^{3} \mathrm{~kg}^{-1}$. These three municipalities have developed economies with relatively more developed agricultural irrigation systems, so irrigation water consumption was relatively larger than that of other regions. Regions in Northwest China had higher $\mathrm{VWC}_{\text {direct, blue values, perhaps because the effec- }}$ tive precipitation in these regions was limited, making it necessary to increase the irrigation water supply for crops.

The $\mathrm{VWC}_{\text {direct, blue }}$ values for rice in Southwest China were relatively low (Fig. 3). The $\mathrm{VWC}_{\text {direct, blue values in }}$ Chongqing, Guizhou, Sichuan and Yunnan were less than $0.16 \mathrm{~m}^{3} \mathrm{~kg}^{-1}$ because in these four regions the effective precipitation can almost meet the water requirements of rice, so the actual irrigation water consumption was limited. Jilin, Shandong and Henan were the other three regions with relatively low $\mathrm{VWC}_{\text {direct, blue }}$ of rice. Limited irrigation water consumption in the three regions might only meet less than $25 \%$ of the irrigation requirement of rice. Therefore, the $\mathrm{VWC}_{\text {direct, blue of rice in Jilin, Shandong and Henan was }}$ relatively low. 


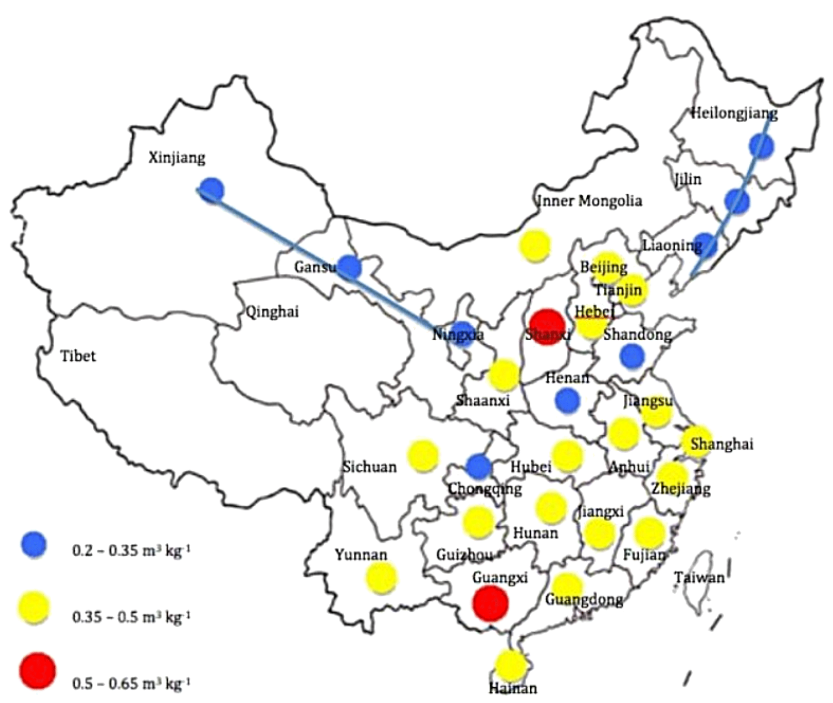

Figure 4. Direct grey water of rice $\left(\mathrm{m}^{3} \mathrm{~kg}^{-1}\right)$.

\subsection{Direct grey water of rice}

The $\mathrm{VWC}_{\text {direct, grey }}$ values of rice ranged from 0.21 to $0.64 \mathrm{~m}^{3} \mathrm{~kg}^{-1}$ with an average $0.37 \mathrm{~m}^{3} \mathrm{~kg}^{-1}$. Regional differences in $V_{W W C}$ direct, grey for rice were insignificant (Fig. 4). Because nitrogen use is similar between regions, VWC $C_{\text {direct, grey }}$ mainly depends on rice yield. The rice yield of regions in Northeast China and Northwest China were relatively high, making the $\mathrm{VWC}_{\text {direct, grey }}$ of rice in Northeast China and Northwest China relatively low. The rice yield of Shandong, Henan and Chongqing was much higher than the national average. That made the $\mathrm{VWC}_{\text {direct, }}$ grey of rice in the three regions also relatively low. The highest $\mathrm{VWC}_{\text {direct, grey }}$ values for rice were in Shanxi and Guangxi, because the rice yields of Shanxi and Guangxi in 2007 were the two lowest of all the regions studied.

\subsection{Total VWC of rice}

The $\mathrm{VWC}_{\text {total }}$ values of rice for 29 regions are calculated and shown in Fig. 5. There were large differences in $\mathrm{VWC}_{\text {total }}$ between regions, with values ranging from 0.80 to $2.59 \mathrm{~m}^{3} \mathrm{~kg}^{-1}$. The average $\mathrm{VWC}_{\text {total }}$ of rice was $1.39 \mathrm{~m}^{3} \mathrm{~kg}^{-1}$. The $\mathrm{VWC}_{\text {total }}$ values showed a roughly threetiered distribution, gradually decreasing from the southeast to the northwest of China. The $\mathrm{VWC}_{\text {total }}$ values in eastern coastal China, Southeast China, Beijing and Tianjin were relatively high. The regions with lower $\mathrm{VWC}_{\text {total }}$ values were mainly concentrated in Northeast China and Northwest China.

Our result is very different from the result of Sun et al. (2013a). Their calculation of the VWC of rice was relatively low in the eastern part of Northeast China, middlelower reaches of the Yangtze River and the eastern part of Southwest China. In contrast, the high values of VWC for

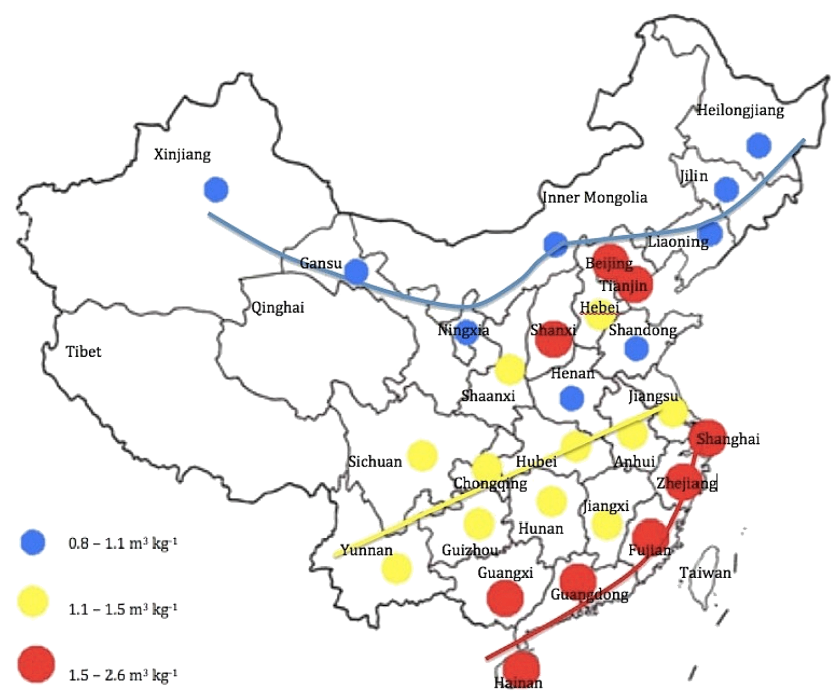

Figure 5. Total VWC of rice $\left(\mathrm{m}^{3} \mathrm{~kg}^{-1}\right)$.

rice were located in the west of Inner Mongolia and the south of the Xinjiang Uygur autonomous region. Their calculation framework only considered the crop water requirement. However, our calculation framework considers the effective precipitation, crop evapotranspiration, irrigation water consumption, freshwater that is required to assimilate the load of pollutants, and the indirect water use. The difference of the $\mathrm{VWC}_{\text {direct, blue }}$ and the added $\mathrm{VWC}_{\text {direct, grey }}$ of rice caused the large difference of spatial distribution characteristic between actual $\mathrm{VWC}_{\text {total }}$ of rice and the rice water requirement. Our result better describes the spatial distribution characteristic of actual water use of rice in China.

\section{Discussion}

\subsection{Comparison of calculations of total VWC of rice by different frameworks}

Here, we compare four frameworks for total VWC determinations (Table 1). (1) In the crop water requirement (CWR) calculation framework, the total virtual water content of crops is divided into green and blue water. Green water use is the lesser of the potential crop evapotranspiration and the effective precipitation. Blue water use is the irrigation water requirement, which is the potential crop evapotranspiration minus green water use (Siebert and Döll, 2010; Sun et al., 2013a). (2) In the green, blue and grey water (GBG) calculation framework, the total virtual water content of crops is divided into green, blue and grey water. The calculation methods for green and blue water are the same as in the CWR framework. Grey water is calculated by multiplying the fraction of nitrogen that leaches or runs off by the nitrogen application rate and dividing this by the difference between the maximum acceptable concentration of nitrogen and the 
Table 1. Comparison of VWC calculation frameworks.

\begin{tabular}{lrrrr}
\hline VWC Method & $\mathrm{VWC}_{\text {direct, green }}$ & $\mathrm{VWC}_{\text {direct, blue }}$ & $\mathrm{VWC}_{\text {direct, grey }}$ & $\mathrm{VWC}_{\text {indirect }}$ \\
\hline Our method & $10 \min \left(\mathrm{ET}_{\mathrm{C}}, P_{\mathrm{e}}\right) / Y$ & $\mathrm{VWC}_{\text {direct, blue }}=I_{\mathrm{c}} / Y=\frac{W_{A} \alpha_{i}}{A_{i}} / Y$ & $\mathrm{VWC}_{\text {direct, grey }}=\frac{N_{\mathrm{c}} \times 10 \%}{10-N_{\mathrm{n}}} / Y$ & $\mathrm{VWC}_{\text {indirect }}=\frac{\mathrm{VW}_{\text {blue, indirect }} \beta_{i}}{A_{i}} / Y$ \\
Sun's method & $10 \mathrm{~min}\left(\mathrm{ET}_{\mathrm{C}}, P_{\mathrm{e}}\right) / Y$ & $\mathrm{VWC}_{\mathrm{direct}, \text { blue }}=I_{\mathrm{c}} / Y=\frac{W_{A} \alpha_{i}}{A_{i}} / Y$ & & - \\
GBG method & $10 \mathrm{~min}\left(\mathrm{ET}_{\mathrm{C}}, P_{\mathrm{e}}\right) / Y$ & $10 \max \left(0, \mathrm{ET}_{\mathrm{c}}-P_{\mathrm{e}}\right) / Y$ & $\mathrm{VWC}_{\text {direct, grey }}=\frac{N_{\mathrm{c}} \times 10 \%}{10-N_{\mathrm{n}}} / Y$ & - \\
CWR method & $10 \min \left(\mathrm{ET}_{\mathrm{C}}, P_{\mathrm{e}}\right) / Y$ & $10 \max \left(0, \mathrm{ET}_{\mathrm{c}}-P_{\mathrm{e}}\right) / Y$ & & - \\
\hline
\end{tabular}

Table 2. The volume $\left(\mathrm{m}^{3} \mathrm{~kg}^{-1}\right)$ and proportion (\%) of VWC of rice in Heilongjiang Province by four different frameworks.

\begin{tabular}{lrrrrr}
\hline VWC Method & VWC $_{\text {direct, green }}$ & VWC $_{\text {direct, blue }}$ & VWC $_{\text {direct, grey }}$ & VWC $_{\text {indirect }}$ & VWC $_{\text {total }}$ \\
\hline Our method & $0.45(46.0)$ & $0.29(30.2)$ & $0.22(22.9)$ & $0.01(0.9)$ & 0.97 \\
Sun's method & $0.45(60.5)$ & $0.29(39.5)$ & - & - & 0.74 \\
GBG method & $0.45(26.6)$ & $1.01(60.1)$ & $0.22(13.3)$ & - & 1.68 \\
CWR method & $0.45(30.7)$ & $1.01(69.3)$ & - & - & 1.45 \\
\hline
\end{tabular}

natural concentration of nitrogen in the receiving water body (Chapagain et al., 2006; Bulsink et al., 2010; Mekonnen and Hoekstra, 2011b). (3) In Sun's framework, the total virtual water content of crops is also divided into green and blue water. Blue water is calculated according to actual irrigation water consumption (Sun et al., 2013b). (4) In our framework, the total virtual water content of crops is divided into direct green, direct blue, direct grey and indirect water. The calculations for green and grey water are the same as in the GBG framework and the calculation method for blue water is the same as in Sun's framework. As described previously, we add indirect water to the total VWC of crops. However, in our calculation framework of the VWC of crops, we made some assumptions and simplifications in the calculation of $\mathrm{VWC}_{\text {indirect }}, \mathrm{VWC}_{\text {direct, blue }}$ and $\mathrm{VWC}_{\text {direct, grey, }}$, which causes some uncertainty in the results. The uncertainty of the results cannot be completely eliminated. We could only make better assumptions and simplifications and use more accurate data to make our results more accurate.

The VWC of rice of Heilongjiang Province in 2007 is used as an example to compare results among the four different frameworks. As shown in Table 2, $\mathrm{VWC}_{\text {total }}$ calculated by our framework is $0.97 \mathrm{~m}^{3} \mathrm{~kg}^{-1}$, which accounts for 66.9, 57.7 and $133.8 \%$ of the $\mathrm{VWC}_{\text {total }}$ of rice under the CWR framework, GBG framework, and Sun's framework, respectively. The $\mathrm{VWC}_{\text {total }}$ calculated by our framework is lower than the $\mathrm{VWC}_{\text {total }}$ calculated by CWR framework and GBG framework, because the $\mathrm{VWC}_{\text {direct, blue }}$ is calculated by the crop irrigation water requirement under CWR framework and GBG framework and calculated by the actual irrigation consumption under our framework. According to the calculation in our method, the actual irrigation consumption cannot meet the irrigation water requirement of rice in Heilongjiang. The $\mathrm{VWC}_{\text {direct, blue value calculated from the actual irriga- }}$ tion consumption under our framework is much lower than

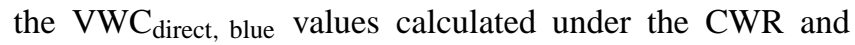

GBG frameworks. Adding the $\mathrm{VWC}_{\text {direct, grey }}$ value resulted in the $\mathrm{VWC}_{\text {total }}$ calculated by our framework being larger than the $\mathrm{VWC}_{\text {total }}$ calculated by Sun's framework. The contribution of $\mathrm{VWC}_{\text {direct, grey }}$ is very important, accounting for $22.9 \%$ of the $\mathrm{VWC}_{\text {total }}$ of rice under our framework, and cannot be ignored. The contribution of $\mathrm{VWC}_{\text {indirect }}$ as calculated under our framework is limited and has little effect on the $\mathrm{VWC}_{\text {total }}$ of rice in Heilongjiang.

\subsection{Analysis of VWC structures of rice in China}

Regional differences in $\mathrm{VWC}_{\text {total }}$ values for rice were significant, as were regional differences in the structure of the $\mathrm{VWC}_{\text {total }}$ of rice. The average $\mathrm{VWC}_{\text {total }}$ of rice in China was $1.39 \mathrm{~m}^{3} \mathrm{~kg}^{-1}$. The percentages of $\mathrm{VWC}_{\text {direct, green, }}$ $\mathrm{VWC}_{\text {direct, blue }}, \mathrm{VWC}_{\text {direct, grey }}$ and $\mathrm{VWC}_{\text {indirect }}$ in the $\mathrm{VWC}_{\text {total }}$ for rice in China were 43.8, 28.2, 27.6 and $0.4 \%$, respectively.

Generally speaking, the regions in China mostly had a higher $\mathrm{VWC}_{\text {direct, green }}$ of rice and a lower $\mathrm{VWC}_{\text {direct, blue }}$ of rice. For example, in Chongqing the percentage of $\mathrm{VWC}_{\text {direct, green }}$ was $67.6 \%$ and the percentage of $\mathrm{VWC}_{\text {direct, blue was }} 6.6 \%$; in Sichuan the percentage of $\mathrm{VWC}_{\text {direct, green }}$ was $53.7 \%$ and the percentage of $\mathrm{VWC}_{\text {direct, blue was }} 12.4 \%$. Six regions were exceptions, having lower $\mathrm{VWC}_{\text {direct, green }}$ of rice and

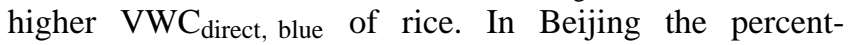
age of $\mathrm{VWC}_{\text {direct, green }}$ was $19.8 \%$ and the percentage of $\mathrm{VWC}_{\text {direct,blue }}$ was $63.2 \%$; in Tianjin the percentage of $\mathrm{VWC}_{\text {direct, green }}$ was $14.7 \%$ and the percentage of $\mathrm{VWC}_{\text {direct, blue }}$ was $69.1 \%$; in Fujian the percentage of $\mathrm{VWC}_{\text {direct, green }}$ was $29.9 \%$ and the percentage of $\mathrm{VWC}_{\text {direct, blue }}$ was $49.7 \%$; in Gansu the percentage of $\mathrm{VWC}_{\text {direct, green }}$ was $33.5 \%$ and the percentage of $\mathrm{VWC}_{\text {direct, blue }}$ was $37.9 \%$; in Ningxia the percentage of $\mathrm{VWC}_{\text {direct, green }}$ was $24.9 \%$ and the percentage of 
$\mathrm{VWC}_{\text {direct, blue }}$ was $48.1 \%$; and in Xinjiang the percentage of $\mathrm{VWC}_{\text {direct, green }}$ was $12.1 \%$ and the percentage of $\mathrm{VWC}_{\text {direct, blue }}$ was $61.6 \%$. There are two reasons for the different situation of the six regions. Excessive consumption of irrigation water caused a lower percentage of $\mathrm{VWC}_{\text {direct, }}$ green of rice and a higher percentage of $\mathrm{VWC}_{\text {direct, blue of rice }}$ in Beijing, Tianjin and Fujian. Limited precipitation caused a lower percentage of $\mathrm{VWC}_{\text {direct, green }}$ of rice and a higher

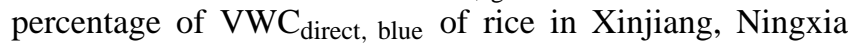
and Gansu. For the country as a whole, the proportion

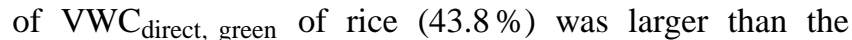
$\mathrm{VWC}_{\text {direct, blue }}$ of rice $(28.2 \%)$. Rice growth mainly depends on the $\mathrm{VWC}_{\text {direct, green in China. }}$

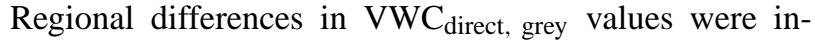
significant. This shows that the grey water in all regions plays an important role in $\mathrm{VWC}_{\text {total }}$. Agricultural pollution is an important issue in every region that cannot be ignored. Because the direct grey water estimated only considers chemical fertilizer pollution, and not the effect of pesticides and herbicides on water quality, the result of this estimation is a conservative estimate.

The values of $\mathrm{VWC}_{\text {indirect }}$ in the $\mathrm{VWC}_{\text {total }}$ of rice for the 29 regions were comparatively low, ranging from 0.001 to $0.010 \mathrm{~m}^{3} \mathrm{~kg}^{-1}$. The average $\mathrm{VWC}_{\text {indirect }}$ of rice was $0.004 \mathrm{~m}^{3} \mathrm{~kg}^{-1}$. $\mathrm{VWC}_{\text {indirect }}$ of rice is related to the degree of regional economic development. The region with the highest $\mathrm{VWC}_{\text {indirect }}$ value was Beijing and the region with the lowest value was Ningxia. Because of the small contribution of $\mathrm{VWC}_{\text {indirect }}, \mathrm{VWC}_{\text {indirect }}$ may not be considered in future research on the $\mathrm{VWC}$ of rice. However, the $\mathrm{VWC}_{\text {indirect }}$ is expected to be higher in some agricultural products, such as potatoes, cotton and fruits, so $\mathrm{VWC}_{\text {indirect }}$ should be included in the $\mathrm{VWC}_{\text {total }}$. For example, the proportion of $\mathrm{VWC}_{\text {indirect }}$ in the $\mathrm{VWC}_{\text {total }}$ of strawberry in 27 regions of China in 2007 ranged from 0.8 to $38.0 \%$, with an average of $10.8 \%$. The proportion of $\mathrm{VWC}_{\text {indirect }}$ of strawberry is higher in the $\mathrm{VWC}_{\text {total }}$. Therefore we cannot ignore the $\mathrm{VWC}_{\text {indirect }}$ in the calculation of the $\mathrm{VWC}_{\text {total }}$ of some crops.

Assessing the VWC of crops is important to provide the basis for agricultural water resources management, and help to improve the efficiency of agricultural water use. Overall pressure on water resources might be relieved by locating water-intensive production processes in regions where water is abundant and where it requires less VWC of product.

\section{Conclusions}

Faced with increasingly severe pressure on water resources, virtual water theory provides a feasible solution to improve global water use efficiency. Research on the VWC of crops can provide the basis for agricultural water resources management and help to improve the efficiency of agricultural water use. Rice is the most important food crop in China and also one of the largest water consumers, so it is important to study the total VWC of rice in China. Previous research constructed calculation frameworks using direct green water, direct blue water and direct grey water of crops. Building on that previous research, we also considered the indirect water of VWC. In this paper, we calculated the virtual water content of rice for 29 regions of China in 2007. The following conclusions were reached.

1. Analysis showed that the total VWC of rice in China decreased gradually from southeast to northwest.

2. The regions with high indirect water were randomly distributed. The indirect VWC of rice in Northwest China and Southwest China was relatively low.

3. The regions with higher direct green water were mainly concentrated in Southeast China and Southwest China. The direct green water of rice for Northwest China and Inner Mongolia was relatively low. The regions with higher direct blue water of rice were mainly concentrated in the eastern and southern coastal regions of China and in Northwest China. The direct blue water of rice of Southwest China was relatively low. In the country as a whole, the percentage of direct green water of rice was far above that of direct blue water. Therefore, rice growth is mainly dependent on direct green water in China.

4. The direct grey water of rice in Northeast China and Northwest China was relatively low. But in all regions, grey water occupies a very important position in total VWC.

Acknowledgements. We thank the International Science \& Technology Cooperation Programme of China (No. 2011DFA72420), the National Science Foundation for Innovative Research Group (No. 51121003), the National Basic Research Programme of China (No. 2010CB951104), and the Fundamental Research Funds for the Central Universities for their financial support.

Edited by: Y. Cai

\section{References}

Allan, J. A.: Overall perspectives on countries and regions, in: Water in Arab World: Perspectives and Progress, edited by: Rogers, P. and Lydon, P., Harvard University Press, Cambridge, UK, 65100, 1994.

Allan, J. A.: The Middle East Water Question: Hydropolitics and the Global Economy, Tauris Publishers, London, UK, 2002.

Allen, R. G., Pereira, L. S., Raes, D., and Smith, M.: Crop evapotranspiration - guidelines for computing crop water requirements, FAO Irrigationand Drainage Paper 56, FAO, Rome, 1998.

Bulsink, F., Hoekstra, A. Y., and Booij, M. J.: The water footprint of Indonesian provinces related to the consumption of crop products, Hydrol. Earth. Syst. Sci., 14, 119-128, doi:10.5194/hess14-119-2010, 2010 
Chapagain, A. K. and Hoekstra, A. Y.: The global component of fresh water demand and supply: an assessment of virtual water flows between nations as a result of trade in agricultural and industrial products, Water. Int., 33, 19-32, 2008.

Chapagain, A. K. and Hoekstra, A. Y.: The blue, green and grey water footprint of rice from production and consumption perspectives, Ecol. Econ., 70, 749-758, 2011.

Chapagain, A. K., Hoekstra, A. Y., Savenije, H. H. G., and Gautam, R.: The water footprint of cotton consumption: an assessment of the impact of worldwide consumption of cotton products on the water resources in the cotton producing countries, Ecol. Econ., 60, 186-203, 2006.

Chen, X. K.: Shanxi water resource input-occupancy-output table and its application in Shanxi Province of China, in: The 13th International Conference on Input-output Techniques, Macerata, Italy, 21-25 August 2000, 2-11, 2000.

China Meteorological Administration: China Meteorological Data Sharing Service System, Beijing, China, available at: http://cdc. cma.gov.cn (last access: 6 September 2011), 2011.

Clarke, D.: CROPWAT for Windows: User Guide, University of Southampton, UK, 1998.

FAO (Food and Agriculture Organization): Land and Water Development Division, CROPWAT model, Food and Agriculture Organization, Rome, Italy, available at: http://www.fao. org/nr/water/infores_databases_cropwat.html (last access: 9 June 2011), 2003.

Hoekstra, A. Y. and Chapagain, A. K.: The water footprints of Morocco and the Netherlands: global water use as a result of domestic consumption of agricultural commodities, Ecol. Econ., 64, 143-151, 2007.

Hoekstra, A. Y. and Hung, P. Q.: Virtual water trade: A quantification of virtual water flows between nations in relation to international crop trade. Value of Water Research Report Series No. 11, UNESCO-IHE, Delft, The Netherlands, 2002.

Hoekstra, A. Y., Chapagain, A. K., Aldaya, M. M., and Mekonnen, M. M.: The Water Footprint Assessment Manual: Setting the Global Standard, Earthscan, London, UK, 2011.

Kanada, N.: Land resources and international trade, Taga Shuppan, Tokyo, 2001.

Leontief, W.: The Structure of the American Economy, Oxford University Press, Oxford, UK, 1941.

Li, H. L., Zhang, W. F., Zhang, F. S., Du, F., and Li, L. K.: Chemical fertilizer use and efficiency change of main grain crops in China, J. Plant Nutrit. Fertiliz., 16, 1136-1143, 2010 (in Chinese).

Liu, J. G., Wiberg, D., Zehnder, A. J. B., and Yang, H.: Modelling the role of irrigation in winter wheat yield, crop water productivity, and production in China, Irrig. Sci., 26, 21-33, 2007
Mekonnen, M. M. and Hoekstra, A. Y.: The green, blue and grey water footprint of crops and derived crop products, Hydrol. Earth. Syst. Sci., 15, 1577-1600, doi:10.5194/hess-15-15772011, 2011a.

Mekonnen, M. M. and Hoekstra, A. Y.: National water footprint accounts: The green, blue and grey water footprint of production and consumption, Value of Water Research Report Series No. 50, UNESCO-IHE, Delft, Netherlands, 2011b.

Ministry of Agriculture of the People's Republic of China: Chinese agricultural statistical data, Ministry of Agriculture of the People's Republic of China, Beijing, 2008.

Ministry of Water Resources: China Water Resources Bulletin 2011, China Water \& Power Press, Beijing, 2012.

Rost, S., Gerten, D., Bondeau, A., Lucht, W., Rohwer, J., and Schaphoff, S.: Agricultural green and blue water consumption and its influence on the global water system, Water. Resour. Res., 44, W09405, doi:10.1029/2007WR006331, 2008.

Siebert, S. and Döll, P.: Quantifying blue and green virtual watercontents in global crop production as well as potential production losses without irrigation, J. Hydrol., 384, 198-207, 2010.

Sun, S. K., Wu, P. T., Wang, Y. B., and Zhao, X. N.: The virtual water content of major grain crops and virtual water flows between regions in China, J. Sci. Food. Agric., 93, 1427-1437, 2013a.

Sun, S. K., Wu, P. T., Wang, Y. B., Zhao, X. N., Liu, J., and Zhang, X. H.: The impacts of interannual climate variability and agricultural inputs on water footprint of crop production in an irrigation district of China, Sci. Total Environ., 444, 498-507, $2013 \mathrm{~b}$.

Yu, P. P., Zhang, J. Z., and Lin, C. G.: Agricultural development strategy of China in the early 21 st century, Resour. Environ. Dev., 7, 21-27, 2006 (in Chinese)

Zhang, S. D., Zhang, W. F., Wang, J. Q.: Character of Fertilizer Consumption and Supply- Demand and Strategy for Management in Middle and Lower Reaches of Yangtz River of China, Res. Agr. Modern., 29, 100-103, 2008 (in Chinese).

Zhang, S. D., Zhang, W. F., and Ma, L.: Study on the change of fertilizer consumption structure of main grain crop in Hebei, Jilin and Sichuan of China, Phosphate Compound Fertilizer, 24, 8991, 2009 (in Chinese).

Zhang, Z. Y., Yang, H., and Shi, M. J.: Analyses of water footprint of Beijing in an interregional input-output framework, Ecol. Econ., 70, 2494-2502, 2011.

Zhao, X., Chen, B., and Yang, Z. F.: National water footprint in an IO framework: A case study of China 2002, Ecol. Model., 220, 245-253, 2009. 